\title{
Poly-3-hydroxybutyrate Biosynthesis by Municipal Sewage Sludge Isolated Bacillus megaterium Utilizing a Pleustophytic Ecological Plague in the Legendry Source of River Nile as the Sole Carbon Source
}

Timothy Omara ${ }^{1,2,3,4^{*}}$, Fortunate Laker ${ }^{1}$, Raymond Kalukusu ${ }^{1,4}$, Bashir Musau ${ }^{1,4}$, Stephen Ssebulime ${ }^{1,5}$, Winfred Nassazi ${ }^{1,6}$

${ }^{1}$ Department of Chemistry, Faculty of Science, Kyambogo University, Jinja Road, Kyambogo, Kampala, Uganda

${ }^{2}$ Department of Food Science, School of Food Technology, Chemistry and Pharmacy, University of Reading, Reading, United Kingdom

${ }^{3}$ Department of Quality Control, Quality Assurance and Product Development, AgroWays Uganda Limited, 34-60Kyabazinga Way, Jinja, Uganda

${ }^{4}$ Department of Quality Control and Quality Assurance, Leading Distillers Uganda Limited, Mengo, Kampala, Uganda

${ }^{5}$ Directorate of Government Analytical Laboratory, Ministry of Internal Affairs, Wandegeya, Kampala, Uganda

${ }^{6}$ Department of Chemistry and Biochemistry, Moi University, Uasin Gishu County, Eldoret, Kenya

*Corresponding Author: prof.timo2018@gmail.com/timothy.omara@agroways.ug,+256-781-373-050

\begin{abstract}
Environmental isolates, genetically manipulated organisms, plants, animals and their products and economical methods are being expertly explored to biosynthesize poly-3-hydroxybutyrate plastics of comparable properties to petroplastics. This study assessed a hypothesized feasibility of utilizing a proliferative pleustophytic greenery, water hyacinth (Eichhornia crassipes (Mart.) Solms-Laubach) in Lake Victoria, Uganda as a potential carbon source for poly-3-hydroxybutyrate biosynthesis. The poly-3-hydroxybutyrate biosynthesizing bacteria (Bacillus megaterium) was isolated from municipal sewage sludge and harnessed for batch fermentation of acid-catalysed water hyacinth biomass. Poly-3-hydroxybutyrate formed in the cytoplasm of the bacterial cells was extracted by chloroform extraction method, and thereof confirmed and quantified by UV spectroscopy. Batch fermentation was carried out in $100 \mathrm{ml}$ of the culture media in a 250ml fermenter for different times (48, 96, 144 and 192 hours) to determine the best incubation time for maximum yield. An all-out net yield of $61.3 \%$ was realized after 96 hours of fermentation. Utilization of this ecological plague for poly-3-hydroxybutyrate biosynthesis is a promising strategy for regulating the weed population along the length of Nile River and the Victorian basin.
\end{abstract}

Keywords: batch fermentation, Lake Victoria, ornamental verdure, poly-3-hydroxybutyrate, sewage sludge

\subsection{Introduction}

Water hyacinth is a pernicious invasive and cosmopolitan greenery with credited floral beauty on Lake Victoria. It is a perennial aquatic herb of the pickerelweed family (Pontederiaceae) and is a native of tropical America [1]. It is attested to have been introduced into East Africa as an ornamental verdure and progressed into the world's second largest fresh water lake via the Rwandese Kagera river [1]. Owing to the available suitable growth 
conditions, total absence of omnivorous predators, elevated trace metal pollution and spacious environment of Lake Victoria, the plant has flourished [1]. The plant itself is morphologically plastic, propagates prolifically and is highly flexible to variations in temperature, light intensity, water $\mathrm{pH}$ and salinity [2]. Thus, it has a swift mode of proliferation, enabling it to adapt to distant dispersal and colonization of various aquatic niches.

In 1995, the weed choked $90 \%$ of the Victorian shoreline with giant mats witnessed in hectarages of Murchison, Wazimenya and Gobero bays. Port Bell (Luzira) and Kasensero (Rakai) of Uganda are among the frequently hit landing sites by the weed resurgence [3]. In Uganda, resurgence was still observed on Kagera River, MacDonald, Fielding, Bunjako, Murchison, Lwera, Napoleon Gulf, Berkeley and some Ssesse Island bays in 2012 [4] and has since threatened the harvest of tilapia, Nile perch and silver fish (omena) [5].

The weed is a menace, impedes boat access, block communal water points along Victorian shorelines [3] and in prolific cases increase the rate of spread of diseases such as bilharzia, malaria [6], skin rush, cough, encephalitis and digestive disorders. It also hampers water treatment, hydroelectricity generation and irrigation operations [7]. Floating mats of the weed curtail light penetration into L. Victoria, limiting growth of photosynthetic phytoplankton [1].

Although it is a deleterious aquatic weed, it is an excellent source of biomass with an estimated hectare (ha) yield of $7 \times 10^{4} \mathrm{~m}^{3} /$ ha of biogas composed of $70 \%$ methane and $30 \%$ carbon dioxide [8]. According to Curtis and Duke [9], a kilogram of water hyacinth dry matter yields 370 litres of biogas, with a heating value of $22,000 \mathrm{~kJ} / \mathrm{m}^{3}$, far better than pure methane gas. E. crassipes is reported to bioremediate trace metals: iron, zinc, sodium, potassium, magnesium and calcium in distillery effluent [10] and Lead, Mercury, Strontium-90, carcinogenic organic compounds, nitrogen [11-13] and potassium [14] in water. The weed leaf concoction is phytotoxically effective against Mimosa pigra and Vigna radiata [15]. Water hyacinth is a starting material for the production of various furniture, handbags, ropes, potash, livestock feed [16] for pigs (though it is reportedly not so palatable owing to the presence of oxalate crystals in the leaves that cause mouth irritation), biofertilizers (compost or mulch) [1719], paper manufacture [20], superabsorbent polymer material synthesis [21] and biosynthesis of poly-3hydroxybutyrate bioplastics due to its high carbonaceous content $[2,22]$.

\subsection{Poly-3-hydroxybutyrate}

Poly-3-hydroxybutyrate (frequently called poly-beta-hydroxybutyrate) is a fully decomposable member of the biopolyester family with optical activity, piezoelectricity and excellent barrier properties. It is a partly crystalline thermoplastic with a high melting point and its biosynthesis is sustainable for voluminous production at economically reduced costs [23]. Poly-3-hydroxybutyrate, the simplest and most encountered polyhydroxyalkanoate (PHA) have $\mathbf{x}$ and $\mathbf{R}$ in the general structure of PHAs, -[O-CH( $\left.(\mathbf{R})\left(\mathrm{CH}_{2}\right)_{\mathbf{x}} \mathrm{CO}\right]-$ equal to 1 and $\mathrm{CH}_{3}$ respectively [24]. Its properties are comparable to those of isotactic polypropylene and other elastomer petroleum-based plastics thus is gaining attention as a substitute for these plastics [24-26]. In addition, poly-3hydroxybutyrate has low permeability for water, molecular oxygen and carbon dioxide.

Polyhydroxyalkanoates are produced by a range of microbes, cultured under different nutrient and environmental conditions [27]. The biopolyesters are harnessed as energy and carbon storage materials by the microbes in transient abundance (excess) of carbon source with nutritional components such as phosphorous, magnesium, oxygen, nitrogen or sulfur being a limiting factor [28-34]. The biopolymers, naturally lipids, accumulate intercellularly as liquid, mobile or amorphous granules to ensure survival under physiological stress by the 
microbe and may be deposited in an amount equivalent to $90 \%$ of cellular dry weight [35]. Poly-3hydroxybutyrates have melting points between $40-180^{\circ} \mathrm{C}$; are biodegraded in microbe active environments within 5-6 weeks releasing carbon dioxide and water [36,37]. Their biocompatibility coupled with low oxygen permeability makes them suitable for medical applications thus can be used as implants without inflammatory side effects. Other bioplastic applications of poly-3-hydroxybutyrate include its utilization as biodegradable carriers, surgical needles, surgical suture materials, bone tissue substitutes, osteosynthetic materials, bone plates, rivets and tacks [38].

\subsection{Recent Studies Done on Poly-3-hydroxybutyrate Production}

Yüksekdağ and others [39] experimented poly-3-hydroxybutyrate production by two Bacillus species (subtilis 25 and megaterium 12) in nutrient broth at various times between 6 and 48 hours. Their findings revealed $1.01 \times$ $10^{-1} \mathrm{~g} / \mathrm{L}, 1.42 \times 10^{-1} \mathrm{~g} / \mathrm{L}$ production of poly-3-hydroxybutyrate with $18.03 \%$ and $14.79 \%$ yields after 45 hours respectively. After 48 hours, a significant reduction in poly-3-hydroxybutyrate yield was observed. Whereas Poly3-hydroxybutyrate accumulation in the culture broth by the strains were nearly insignificant with the two carbon and nitrogen sources, the highest poly-3-hydroxybutyrate level was noted in protease peptone enriched medium. In this enriched broth, poly-3-hydroxybutyrate yield of $B$. subtilis 25 was $78.69 \%$, whereas in the same nitrogen sources, B. megaterium 12 had $77 \%$ yield [39].

The accumulation of poly-3-hydroxybutyrate granules in the cells of B. megaterium ATCC 6748 was reported to entirely rely on the ratio of carbon and nitrogen sources by Chaijamrus and Udpuay [40]. The investigation utilized sugarcane molasses (MOL) and corn steep liquor (CSL) respectively as renewable sources of carbon and nitrogen. The highest poly-3-hydroxybutyrate production $(43 \% \mathrm{w} / \mathrm{w}$, dry matter) was observed after 45 hours of microbial growth when equal quantities (4\%) of MOL and CSL were experimented, whereas the highest biomass $\left(7.2 \mathrm{gL}^{-1}\right)$ was recorded at $4 \% \mathrm{MOL}$ and $6 \% \mathrm{CSL}$. The team concluded that bacterial growth increased as CSL concentration increased and poly-3-hydroxybutyrate accumulation contrarily decreased. The formation rate of poly-3-hydroxybutyrate up to $0.016 \mathrm{hr}^{-1}$ and specific growth rate of up to $0.25 \mathrm{~h}^{-1}$ were reported during the experimental growth [40]. The chemical structure and thermal properties of poly-3-hydroxybutyrate produced from MOL and CSL were comparable to that of the commercial poly-3-hydroxybutyrate, except for the significantly higher molecular mass (about $3.9 \times 10^{6} \mathrm{Da}$ ) and lower degree of crystallinity.

The effect of various carbonaceous and nitrogenous sources on poly-3-hydroxybutyrate production was investigated by Gouda et al [41]. The highest production of $40.8 \%$ and $39.9 \%$ per mg cell dry matter was achieved with cane molasses and glucose respectively. Optimum growth was achieved with $3 \%$ molasses with maximum yield of $46.2 \%$ per mg cell dry matter of poly-3-hydroxybutyrate was achieved with $2 \%$ molasses. Corn steep liquor was the most sustainable synthetic nitrogen source with a yield of $32.7 \mathrm{mg}$ per cell dry matter. Optimal growth was achieved with the chloride, sulphate, oxalate and/or phosphate of Ammonium ion used as the chief nitrogen source.

A novel B. megaterium strain was isolated and characterized by López et al [42]. Its probable ability to be utilized in poly-3-hydroxybutyrate production was assessed using various fermentation configurations on formulated media. The novel strain gave $59 \%$ and $60 \%$ poly-3-hydroxybutyrate yield of its dry cell weight in bioreactor assessments utilizing glucose and glycerol as the chief carbon sources. Basing on carbon-13 Nuclear Magnetic Resonance and Fourier Transform Infrared analyses, they concluded that despite the sporulation 
phenomenon exhibited by the novel Bacillus strain, its intracellular Poly-3-Hydroxybutyrate biosynthesis potential was higher than those previously reported in literature.

A study conducted by Rodriguez-Contreras et al [43] with a novel B. megaterium strain (uyuni S29) for poly3-hydroxybutyrate biosynthesizing capacity reported a future of considering the strain for industrial poly-3hydroxybutyrate production. The strain gave 70\% Poly-3-Hydroxybutyrate yield in a fermentation reactor against $60 \%$ of biosynthesized polymer that is necessary for recommending a strain as economical for large scale biosynthesis $[44,45]$. More so, the industrial scale conditions utilize conventional medium and moderate salt content; an environment that was already replicated in their previous study [46] and carried on in the aforeacknowledged study.

Unfortunately, voluminous production of poly-3-hydroxybutyrate is not industrially economical due to its prohibitive production cost. The current efforts of researchers aims at reducing the cost of production through identification of efficient bacterial strains $[26,46]$ and potentially cheap substrates. The genus Bacillus received attention [47] due to the stability of its replication and plasmids maintenance. Many Bacillus species have reported poly-3-hydroxybutyrate production potential $[48,49]$. This study reported the feasibility of utilizing the pleustophytic ecological plague, Eichhornia crassipes (Mart.) Solms-Laubach in Lake Victoria, Uganda for batch biosynthesis of poly-3-hydroxybutyrate using B. megaterium isolated from municipal sewage sludge.

\section{Method}

\subsection{Isolation of Poly-3-Hydroxybutyrate Biosynthesizing Bacteria}

Sewage sludge samples were collected from Lubigi Sewage and Faecal Sludge Treatment Plant (SFSTP). The treatment plant, operated by National Water and Sewerage Corporation (NWSC), Kampala, Uganda receives and treats wastewater from a piped network as well as faecal sludge that is brought by private cesspool emptiers. The plant provide $400 \mathrm{~m}^{3}$ per day capacity for faecal sludge treatment [50].

The sludge samples were collected in sterile paper bags and microbiologically analyzed within 2 hours of collection. The bacteria was isolated and identified as B. megaterium. Bacterial isolates from the sludge was crossstreaked on nutrient broth $(2.5 \mathrm{~g} / \mathrm{L}$ peptone, $2.5 \mathrm{~g} / \mathrm{L} \mathrm{NaCl}, 1.0 \mathrm{~g} / \mathrm{L}$ yeast extract and $0.5 \mathrm{~g} / \mathrm{L}$ beef extract $) .100 \mathrm{ml}$ of the cultures in a $250 \mathrm{ml}$ Erlenmeyer flask was inoculated with a $2 \% \mathrm{v} / \mathrm{v}$ inoculum and incubated at $37^{\circ} \mathrm{C}$ for 12 hours with vigorous orbital shaking at $230 \mathrm{rpm}$.

\subsection{Collection and Preparation of the Carbon Source}

Water hyacinth was collected from Port Bell, Luzira, Kampala-Uganda where one of the recent resurgences have been reported [3]. It was washed several times with distilled water and oven dried at $70^{\circ} \mathrm{C}$ for 48 hours. Fine powdered water hyacinth was utilized as the sole carbon source.

Substrate hydrolysate preparation was performed following a modified analytical procedure of Pumiput et al [51]. Aliquots $(8.0 \pm 0.1 \mathrm{~g})$ of a fortnight shade dried powder of water hyacinth leaves (Figure 1 (a)) was steam exploded in an autoclave at $121^{\circ} \mathrm{C}$ for 20 minutes. Distilled water was added to the wet pretreated powder in a $250 \mathrm{ml}$ volumetric flask to top up the volume to the mark. The resultant mixture was subsequently boiled at $80^{\circ} \mathrm{C}$ for 30 minutes and the hydrolysate was recovered by filtration. 
Acid post-hydrolysis of the hydrolysate was performed to split the oligosaccharides in the hydrolysate to monomeric sugars by autoclaving at $121^{\circ} \mathrm{C}$ with $1 \%$ hydrochloric acid $(\mathrm{v} / \mathrm{v})$ for 30 minutes. The $\mathrm{pH}$ of the resultant hydrolysate was adjusted with Sodium hydroxide to 7.0 and the precipitate recovered by filtration through Whatmann No.1 filter paper (Figure 1 (b)) [2,51].

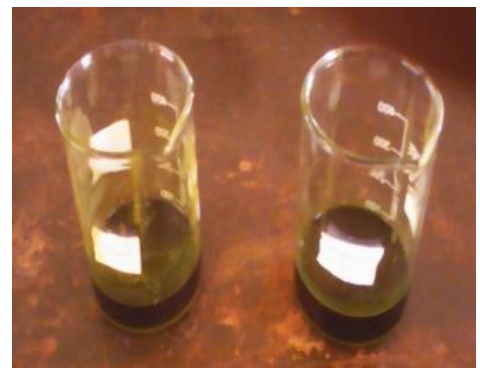

(a)

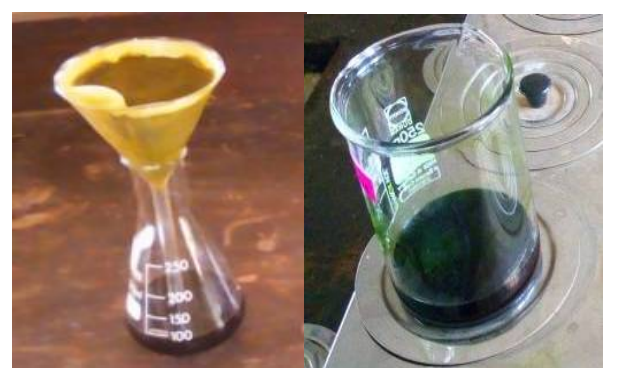

(b)

Figure 1. Water Hyacinth (a) Powdered samples (b) Hydrolysates

\subsection{Poly-3-Hydroxybutyrate Production}

Preliminary screening for the detection of bacterial isolates capable of poly-3-hydroxybutyrate biosynthesis and accumulation was performed using an analytical procedure previously used elsewhere by Zhang et al. [52]. Poly3-hydroxybutyrate production was carried out in a nitrogen-deficient medium. Batch fermentation was carried out in a $250 \mathrm{ml}$ Erlenmeyer flask containing $100 \mathrm{ml}$ of culture medium. The flasks were inoculated and maintained at $30^{\circ} \mathrm{C}$ and 130 rotations per minute for $48,96,144$ and 192 hours.

\subsection{Poly-3-Hydroxybutyrate Extraction, Purification and Quantification}

The isolated culture was employed for mass growth for 2-8 days in a rotary shaker at $37^{\circ} \mathrm{C}$. The samples were centrifuged for 45 minutes at $6,000 \mathrm{rpm}$. The pellets were subsequently incubated at $60^{\circ} \mathrm{C}$ for 1 hour with sodium hypochlorite to break the cell walls of bacteria. Supernatant obtained was transferred to a Soxhlet system. Cell lipids and other molecules (except poly-3-hydroxybutyrate) were extracted by addition of $5 \mathrm{~mL}$ of $96 \%$ (1:1 v/v) ethanol and acetone. Poly-3-hydroxybutyrate was extracted using chloroform. Chloroform extract was dried at $40^{\circ} \mathrm{C}$ and $10 \mathrm{~mL}$ of concentrated sulfuric acid was added. They were heated at $100^{\circ} \mathrm{C}$ in a water bath for 20 minutes.

After cooling, quantification of biosynthesized poly-3-hydroxybutyrate was performed employing an analytical procedure previously used in other studies [2,53-55]. The biopolymer was quantified by UV Visible Spectrometry at $235 \mathrm{~nm}$ using a Double Beam Optimal Geometry Genesys 10S Ultraviolet-Visible spectrophotometer (Thermo Scientific, USA) in comparison with a standard curve plotted between concentrations of crotonic acid and the corresponding absorbances at $235 \mathrm{~nm}$.

For dry cell weight (DCW) analysis, $10 \mathrm{~mL}$ of culture sample was centrifuged at $11,200 \times \mathrm{g}$ for $20 \mathrm{~min}$. The cell pellet was washed twice with $1 \mathrm{~mL}$ of distilled water and transferred to a dry petri dish. The pellet was dried to constant weight at $60^{\circ} \mathrm{C}$ to estimate the $\mathrm{DCW}$ in $\mathrm{g} / \mathrm{mL}$. Three independent replications were performed. The 
percentage of poly-3-hydroxybutyrate accumulated was estimated as the percentage composition of poly-3hydroxybutyrate present in the DCW (measured in $\mathrm{g} / \mathrm{mL}$ ), which was calculated using equation (1):

$$
\text { Poly-3-hydroxybutyrate Accretion }=\frac{\text { Dry weight of PHB }}{\text { Dry cell weight }} \times 100 \%
$$

\subsection{Characterization and Confirmation of the Extracted Polymer}

Characterization and confirmation of poly-3-hydroxybutyrate recovered was done using crotonic acid assay. The powder was dissolved in sulphuric acid $(1 \mathrm{mg} / \mathrm{mL})$ and heated at $100^{\circ} \mathrm{C}$ for 10 minutes to convert it into crotonic acid (brown colored). The solution was cooled, and its spectroscopic absorbance read at 260nm against a concentrated sulphuric acid as blank.

\section{Experimental Results and Discussion}

The average yields of poly-3-hydroxybutyrate from the cells are presented in Table 1.

Table 1. Poly-3-Hydroxybutyrate Yield in the Water Hyacinth Hydrolysate.

\begin{tabular}{|l|l|l|}
\hline Incubation Time (Hours) & Recovered Poly-3-hydroxybutyrate (g/L) & Poly-3-hydroxybutyrate Accretion (\%) \\
\hline 48 & $1.2 \pm 0.0577$ & 15.0 \\
\hline 96 & $4.9 \pm 0.1155$ & 61.3 \\
\hline 144 & $4.2 \pm 0.0577$ & 51.3 \\
\hline 192 & $3.8 \pm 0.1155$ & 47.5 \\
\hline
\end{tabular}

a. Recovered poly-3-hydroxybutyrate is presented as Mean \pm Standard Error, S.E of triplicates.

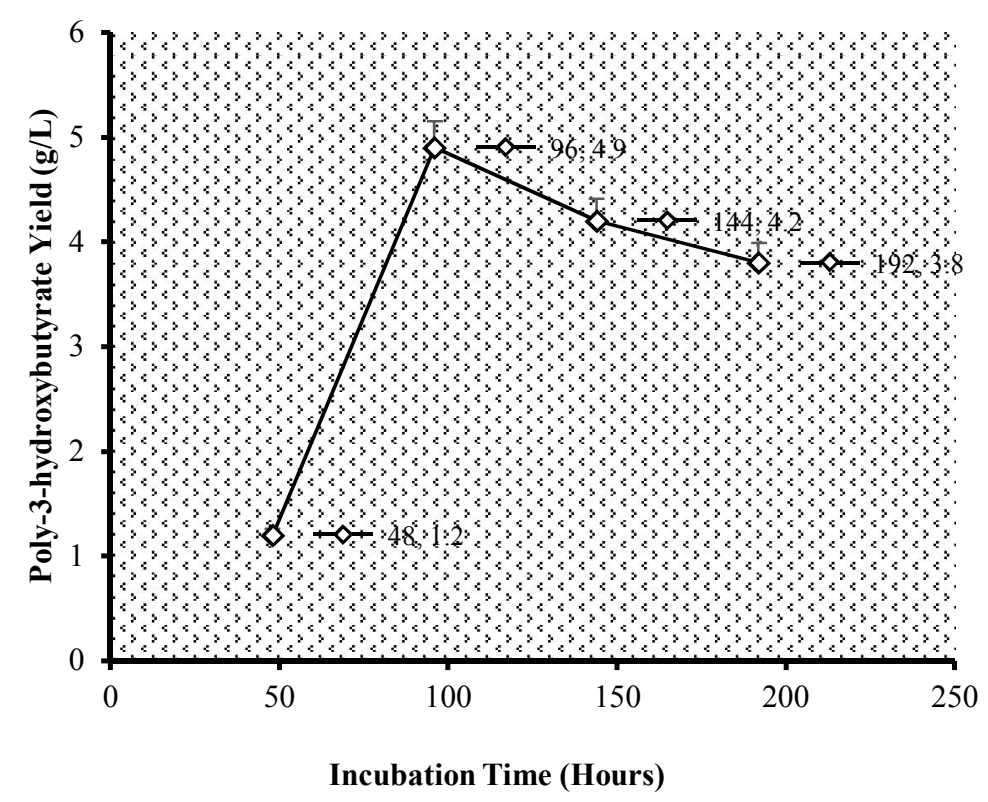

Figure 2. Poly-3-Hydroxybutyrate yield as a function of incubation time 


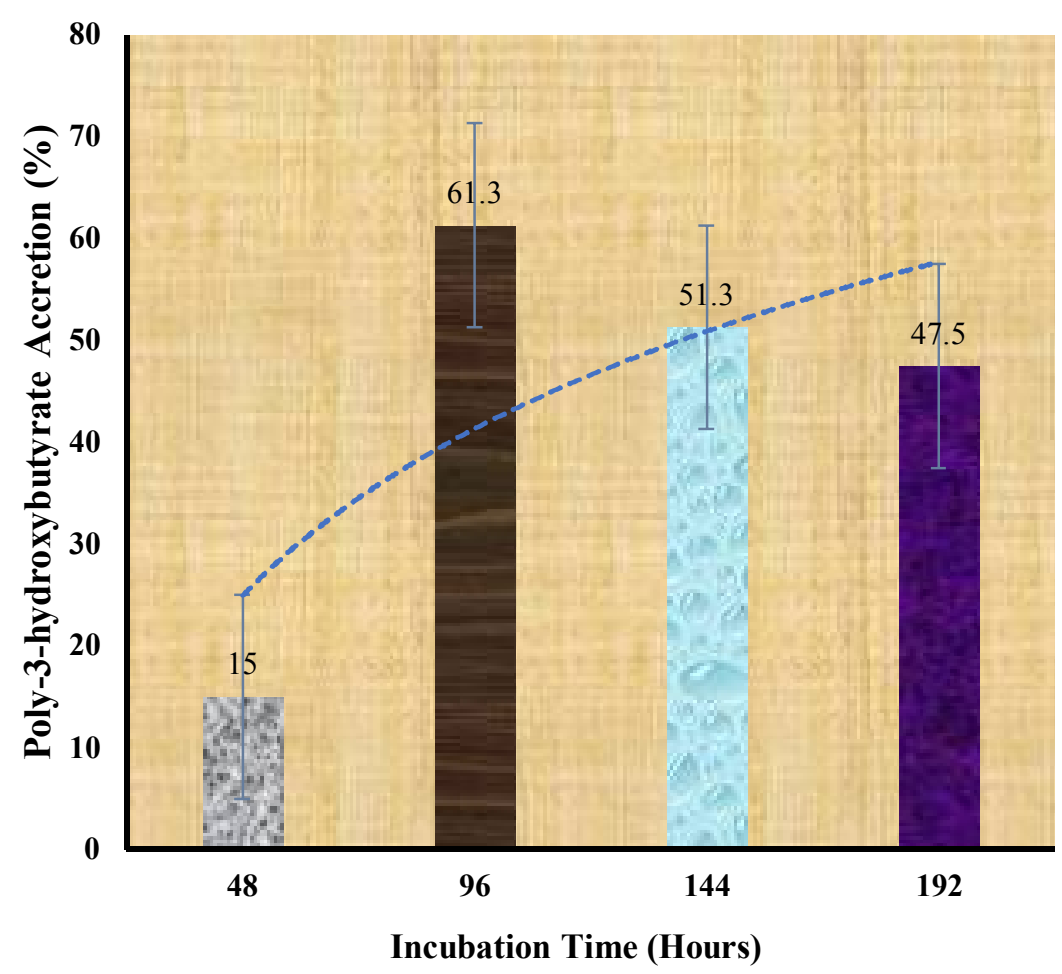

Figure 3. Poly-3-hydroxybutyrate accretion as a function of incubation time

\subsection{Bacterial Staining}

Utilization of the lipophilic stain to specifically stain the intracellular PHA granules accumulated by the sewage sludge isolated B. megaterium is a confirmatory swift routine approach for scrutinization of PHA biosynthesizing bacterial species [56]. The poly-3-hydroxybutyrate biosynthesizing colonies were bluish black and the poly-3hydroxybutyrate granules were recognized by their affinity for the dye Sudan black, which is a presumptive test for presence of poly-3-hydroxybutyrate [57].

\subsection{Hydrolysis of Water Hyacinth}

The acid hydrolysis method of Pumiput et al [51] which was used while investigating lactic acid production from fruit waste registered success in hydrolyzing and harnessing reducing sugars from water hyacinth biomass in this study. This agrees well with the study of Preethi and co-authors [2].

\subsection{Chloroform Extraction of Accumulated Poly-3-Hydroxybutyrate}

Utilization of organic solvents such as chloroform for poly-3-hydroxybutyrate extraction is one of the most employed analytical procedures for recovering PHA and thus poly-3-hydroxybutyrate. It is published that chloroform alters cell membrane permeability of the PHA biosynthesizing bacterial cells and subsequently solubilize the PHA component, releasing it in solution [58]. 


\subsection{Recovered Poly-3-hydroxybutyrate Yield and Accretion}

There was gradual increase in poly-3-hydroxybutyrate biosynthesis by B. megaterium in the water hyacinth medium. A high yield of poly-3-hydroxybutyrate $(4.9 \mathrm{~g} / \mathrm{L}, 61.3 \%$ poly-3-hydroxybutyrate) was realized on the fourth day of fermentation (96 hours) in water hyacinth medium (Table 1; Figure 2; Figure 3). The result of this investigation is corroborant with that observed with Cupriavidus necator [59] and Pseudomonas aeruginosa [2] where PHA yield was as high as $4.3 \mathrm{~g} / \mathrm{L}$. Increase in the fermentation time in this study culminated in a significant decline $(\mathrm{p}<0.05)$ in poly-3-hydroxybutyrate biosynthesis. This could be correlated with the utilization of intracellular PHA granules as reserve food molecules during nutrient starvation [60]. Thus, it can be thought that until sporulation time, the bacteria produced poly-3-hydroxybutyrate and subsequently used it. The decrease in polymer yield after the $96^{\text {th }}$ hour is indicative that the biosynthesizing bacteria utilized the polymer as a source of carbon and nitrogen, triggering unfavorable growth conditions due to depletion of carbon and nitrogen sources in the hydrolysate medium. Bacterial spores are produced during the stationary phase as poly-3-hydroxybutyrate is being biosynthesized and utilized [61,62].

The results of this study is comparable to that of Klüttermann et al [63] who reported that Agrobacterium radiobacter gave a maximum accretion of $60 \%$ poly-3-hydroxybutyrate of cell dry weight in the stationary growth phase after 96 hours with a significant drop in yields reported after this time. Reddy et al [64] also reported that B. megaterium strain OU303A from sewage sludge successfully biosynthesized poly-3-hydroxybutyrate and polyhydroxybutyrate-co-hydroxyvalerate (PHB-co-HV) copolymer. The strain had an all-out yield of $62.43 \%$ DCW polymer in a medium containing glycerol as the sole carbon source, comparatively higher than $58.63 \%$ DCW polymer in glucose as the sole carbon source. Additionally, the strain reportedly produced $2.5 \%$ hydroxyvalerate copolymer from glucose with increase in hydroxyvalerate monomer yield following the inclusion of its copolymer precursor in the fermentation medium.

\subsection{Quantification of Accretioned Poly-3-hydroxybutyrate}

Polyhydroxyalkanoates can be chemically converted quantitatively to crotonic acid by heating in concentrated Sulphuric acid. The UV spectroscopic absorption maximum of crotonic acid is normally shifted to $260 \mathrm{~nm}$ when concentrated sulphuric acid is used as the solvent [56]. Carboxyl compounds absorbs light below the UV range and hence are difficult to detect by spectrophotometry. Crotonic acid assay relies on the chemical fact that UV absorption maxima of alpha and beta unsaturated acids undergoes a strong bathochromic shift (shifts to lower frequency) in sulphuric acid and can be recorded in the UV range; the corresponding absorption maximum is thus shifted to 260nm [56]. The results of this pilot study confirmed that PHA, poly-3-hydroxybutyrate precursor was formed from fermented water hyacinth biomass, which is corroborant with the report of preceding authors $[2,65-$ $67]$.

\section{Conclusion}

From this study, it was evidential that water hyacinth is a potential candidate for poly-3-hydroxybutyrate production in a batch fermenter. Bacillus megaterium successfully fermented the simple sugars in the water hyacinth hydrolysate. The yields of accumulated poly-3-hydroxybutyrate were generally greater for higher fermentation times; the maximum yield obtained was $61.3 \%$ per dry cell mass after 96 hours of fermentation. 
Increase in fermentation time beyond 96 hours did not register any increment in poly-3-hydroxybutyrate yield. The utilization of water hyacinth as a starting substrate for poly-3-hydroxybutyrate biosynthesis using $B$. megaterium isolated from sewage could be a feasible strategy in managing the population of the noxious weed in the Victorian basin and the entire River Nile length. Further research should aim at screening to identify the strain of the bacterium harnessed from the sewage sludge as well as determine the nutritive parameters of the water hyacinth leaves.

\section{Acknowledgements}

The authors are grateful to the Government of the Republic of Uganda for the full scholarships offered to Timothy, Fortunate, Bashir, Stephen and Winfred.

\section{References}

1. J. Gichuki, R. Omondi, P. Boera, T. Okorut, A. SaidMatano, T. Jembe and A. Ofulla. Water Hyacinth Eichhornia crassipes (Mart.) Solms-Laubach Dynamics and Succession in the Nyanza Gulf of Lake Victoria (East Africa): Implications for Water Quality and Biodiversity Conservation. The Scientific World J. Article ID 106429, (2012) 1-10.

2. K. Preethi, Vineetha, M. Umesh. Water Hyacinth: A Potential Substrate for Bioplastic (PHA) Production Using Pseudomonas aeruginosa. Int J Appl Res. 1 (11) (2015), 349-354.

3. The New Vision. $5^{\text {th }}$ November 2012. Water Hyacinth Reinvades Lake Victoria. Accessed 5th August 2018. https://www.newvision.co.ug/new vision/news/1309645/water-hyacinth-invades-lake-victoria

4. F.W. Wanda, M. Namusoke, M. Matuha. Water hyacinth hotspots in the Ugandan waters of Lake Victoria in 1994-2012: Implications for Management. Afr J Aquatic Sci. 40(1) (2015) 101-106.

5. The Daily Monitor. Tuesday October $16^{\text {th }}$ 2012. Water Hyacinth Presents Fresh Fishing Problems. Accessed 18th August 2018.

https://www.google.com/amp/www.monitor.co.ug/Business/Prosper/Water-hyacinth-presents-fresh-fishingproblems/688616-1533664-view-asAMP-nrfjwv/index.html

6. B. Sornvoraweat and J. Kongkiattikajorn. Separated Hydrolysis and Fermentation of Water Hyacinth Leaves for Ethanol Production. J Life Sci. 5(2011) 212-219.

7. G. O. Opande, J.C. Onyang and S.O. Wagai. Lake Victoria: The Water Hyacinth (Eichhornia crassipes (Mart.) Solms), its Socio-Economic Effects, Control Measures and Resurgence in the Winam Gulf. Limnologica. 34(2004) 105-109.

8. National Research Council, 1976. Making Aquatic Weeds Useful: Some Perspectives for Developing Countries. Washington, DC: The National Academies Press. doi:10.17226/19948. ISBN 978-0-309-33457-0. Retrieved $16^{\text {th }}$ November 2018.

9. C.R., Curtis and J.A., Duke. An Assessment of Land Biomass and Energy Potential for the Republic of Panama. Institute of Energy Conversion. University of Delaware, vol. 3, 1982.

10. P. Bathla. Phytoremediation of Metals Contaminated Distillery Effluent using Water Hyacinth (Eichhornia crassipes). Int J Eng Technol Manag Appl Sci. 4(2016) 283-290.

11. L.J. Fox, P.C. Struik, B.L. Appleton, J.H. Rule, et al. Nitrogen Phytoremediation by Water Hyacinth (Eichhornia crassipes (Mart.) Solms). Water, Air and Soil Pollution. 194(2008)199-207. 
12. S.K. Billore, R. Bharadio, A. Kumar, et al. Potential Removal of Particulate Matter and Nitrogen Through Roots of Water Hyacinth in a Tropical Natural Wetland. Current Science, 74:154-56, 1998.

13. A. Ansari, G. Sarvajeet, K. Fareed, G. Naeem. Phytoremediation Systems for the Recovery of Nutrients from Eutrophic Waters. Eutrophication: Causes, Consequences and Control. 2(2014) 239-248.

14. W. Zhou, D. Zhu, L. Tan, S. Liao,H. Hu,H. David, et al. Extraction and Retrieval of Potassium from Water Hyacinth (Eichhornia crassipes). Biores Technol. 98(2007) 226-231.

15. T.T. Chai, J.C. Ngoi, F.C. Wong. Herbicidal Potential of Eichhornia crassipes Leaf Extract against Mimosa pigra and Vigna radiata. Int J Agric Biol. 15(5) (2013) 835-842.

16. H.T. Tham. Utilization of Water Hyacinth as Animal Feed. Nova J Eng Appl Sci. 4(2015) 1-6.

17. Lata, N., Veenapani, D. Response of Water Hyacinth Manure on Growth Attributes and Yields in Brassica juncea. J Cent Eur Agric. 12(2011) 336-343.

18. N. Lata and D. Veenapani. The Impact of Water Hyacinth Manure on Growth Attributes and Yields in Coriandrum sativum. IOSR J Environ Sci Toxicol Food Technol 5(2013) 4-7.

19. S. Vidya and L. Girish. Water Hyacinth as a Green Manure for Organic Farming. Int J Res Appl Nat Soc Sci. 2(2014) 65-72.

20. W.J. Nolad, D.W. Kirmse. The Papermaking Properties of Water Hyacinth. J Aquatic Plant Manag. 12(1974) 90-97.

21. A.B. Pitaloka, A.H. Saputra and M. Nasikin. Water hyacinth for superabsorbent polymer material. World Appl Sci J. 22 (2013) 747-754.

22. R.L. Reddy, V.S. Reddy, G.A. Gupta. Study of Bioplastics as Green and Sustainable Alternative to Plastics. Int J Emerg Technol Adv Eng. 3 (5) (2013) 82-89.

https://pdfs.semanticscholar.org/9e8c/b3ddb5499e2f7226926feed35f87addbaad1.pdf.

23. Y. Poirier. PHA Synthesis in Plants as a Tool for Biotechnology and Basic Studies of Lipid Metabolism. Progress in Lipid Research. 41(2002) 31-55.

24. G.J. McCool, T. Fernandez, N. Li, M.C. Cannon. PHA Inclusion-Body Growth and Proliferation in $B$. megaterium. FEMS Microbiol Letts. 138(1996) 41-48.

25. S. Khanna and A.K. Srivastava. Recent Advances in Microbial PHAs. Process Biochem. 40(2005) 607-619.

26. M. Koller, A. Salerno, M. Dias, A. Reiterer and G. Braunegg. Modern Biotechnological Polymer Synthesis: A Review. Food Technol Biotechnol. 48(2010) 255-269.

27. G. Singh, A. Kumari, A. Mittal, A. Yadav and N.K. Aggarwal. Poly-3-hydroxybutyrate Production by Bacillus subtilis NG220 Using Sugar Industry Waste Water. Biomed Res Int, vol. 2013, Article ID 952641, 10 pages.

28. C. Pedrós-Alió, J. Mas, R. Guerrero. PHA Accumulation in Planktonic and Anaerobic Environments. In: Novel Biodegradable Microbial Polymers (Ed. Dawes, E. A.) Kluwer Academic Publisher. Dordrecht, The Netherlands, pp. 263-74, 1990.

29. A. Steinbüchel, E. Hustede, M. Liebergesell, U. Pieper, A. Timm, H. Valentin. Molecular Basis for Biosynthesis and Accumulation of Polyhydroxyalkanoic Acids in Bacteria. FEMS Microbiol Revs. 103(1992) 217-230.

30. A. Steinbüchel. Polyhydroxyalkanoic Acids. In: Biomaterials, Novel Materials from Biological Sources. (Ed. Byrom, D.). MacMillan Publisher Ltd, Basingstoke, pp. 123-213, 1991. 
31. A.J. Anderson and E.A. Dawes. Occurrence, Metabolism, Metabolic Role and Industrial Uses of Bacterial PHAs. Microbiol Revs. 54(1990) 450-472.

32. A. Steinbuchel and B. Fuchtenbusch.Bacterial and Other Biological Systems for Polyester Production. Trends Biotechnol. 16 (1998) 419-427.

33. M. Bernard. Industrial Potential of PHA Bioplastic: A Brief Review. University of Saskatchewan Undergraduate Res J. 1(2014) 1-14.

34. H.G. Schlegel, G. Gottschalk, R. von Bartta. Formation and Utilization of Poly-Beta-Hydroxybutyric Acid by Knallgas bacteria (Hydrogenomonas). Nature (London. 191(1961) 463-465.

35. S.Y. Lee. Plastic Bacteria? Progress and Prospects for PHA Production in Bacteria. Trends Biotechnol. 14(1996) 431-438.

36. K.G. Harding, J.S. Dennis, H. von Blottnitz, S.T. Harrison. Environmental Analysis of Plastic Production Processes: Comparing Petroleum-Based Polypropylene And Polyethylene With Biologically-Based Poly-BetaHydroxybutyric Acid using Life Cycle Analysis. J Biotechnol. 130 (2007) 57-66.

37. N. K. Naranje, B. J. Wadher, H. J. Purohit, M. G. Muddeshwar. B. megaterium as Potential Producer for PHAs. IOSR J Environ Sci Toxicol Food Tech. 1(6) (2015) 7-10.

38. Z. N. Yüksekdağ, B. Aslım, Y. Beyatli1, N. Mercan. Effect of Carbon and Nitrogen Sources and Incubation Times on Poly-3-hydroxybutyrate Synthesis by Bacillus subtilis 25 and B. megaterium 12. Afr J Biotech. 3(1) (2004) 63-66.

39. S. Chaijamrus and N. Udpuay. Production and Characterization of Poly-3-hydroxybutyrate from Molasses and Corn Steep Liquor produced by B. megaterium ATCC 6748. Agric Eng Int: the CIGR Ejournal. Manuscript FP 07 030. X(2008).

40. M.K. Gouda, A.E. Swellam, S.H. Oma. Production of Poly-3-hydroxybutyrate by a B. megaterium Strain using Sugarcane Molasses and Corn Steep Liquor as Sole Carbon and Nitrogen Sources. Microbiol Res. 156(2001) 201-207.

41. J.A. López, J.M. Naranjo, J.C. Higuita, M.A. Cubitto, C.A. Cardona and M.A. Villar. “'Biosynthesis of poly3-hydroxybutyrate from a New Isolated B. megaterium Strain: Outlook on Future Developments with Endospore Forming Bacteria. Biotechnol Bioproc Eng. 17(2012) 250-258.

42. A. Rodriguez-Contreras, M. Koller, M. Miranda-de Sousa Dias, M. Calafell-Monfort, G. Braunegg and M.S. Marques-Calvo. High Production of Poly(3-Hydroxybutyrate) From a Wild B. megaterium Bolivian Strain. J Appl Microbiol. 114(2013) 1378-1413.

43. R.M. Macrae and J.F. Wilkinson. Poly-3-hydroxybutyrate Metabolism in Washed Suspensions of Bacillus cereus and B. megaterium. J General Microbiol. 19 (1958) 210-222.

44. C.S.K. Reddy, R. Ghai and V.C.R. Kalia. PHAs: An Overview. Biores Tech. 87(2003)137-146.

45. A. Rodrıguez-Contreras, M. Koller, M. Miranda-de Sousa Dias, M. Calafell-Monfort, G. Braunegg and M.S. Marques-Calvo. Novel Poly[(R)-3-hydroxybutyrate]-Producing Bacterium Isolated from a Bolivian Hypersaline Lake. Food Technol Biotechnol. 51(1) (2013)123-130.

46. J. Quillaguaman, H. Guzman, D. Van-Thuoc and R. Hatti-Kaul. Synthesis and Production of PHAs by Halophiles: Current Potential And Future Prospects'. Appl Microbiol Biotechnol. 85(2010) 1687-96. 
47. R. Biedendieck, M. Gamer, L. Jaensch, S. Meyer, M. Rohde, W.D. Deckwer and D. Jahn. “A sucrose inducible promoter system for the intra- and extracellular protein production in B. megaterium', J Biotech. 132 (2007) 426-430.

48. M. Singh, S.-K.S. Patel and V.-C. Kalia. Bacillus subtilis as Potential Producer for PHAs. Microb Cell Fact. $8(2009) 38$.

49. P.Y. Tian, L. Shang, H. Ren, Y. Mi, D.D. Fan and M. Jiang. Biosynthesis of PHAs: Current Research and Development. Afr J Biotech. 8(2009) 709-14.

50. Fichtner. 2014. Lake Victoria WATSAN Project. Package 5A: Development of an Appropriate Sanitation Concept, Review of Water Supply Aspects in Informal Settlements and Feasibility Study. Draft Feasibility Study Report. Volume 1: Report. Prepared for NWSC. July 2014.

51. P. Pumiput, S. Chuntranuluck, V. Kitpreechavanich, V. Punsuron, P. Vaithanomstat.Production Process of Hydrolysate from Steam Explosion of Oil Trunk for Xylitol Fermentation. Kasetsart Journal (National Science). 42(2008) 73-78.

52. Y. Zhang, W. Sun, H. Wang, A. Geng. Poly-3-Hydroxybutyrate Production from Oil Palm Empty Fruit Bunch Using B. megaterium R11. Biores Tech. 147(2013) 307-14.

53. A. Santhanam and S. Sasidharan. Microbial Production of PHA from Alcaligens specie and Pseudomonas oleovorans using Different Carbon Sources. Afr J Biotech. 9(2010) 3144-50.

54. R.R. Bowker. Manual of Methods for General Bacteriology. American Society for Microbiology, Washington. D.C, 1981.

55. M. Kuniko, Y. Nakamura, Y. Doi. New Bacterial Co-Polyesters Produced in Alcaligenes eutrophus from Organic Acids. Polymer Comm. 29(1989) 174-76.

56. J.H. Law and R.A. Slepecky. Assay of Poly-Beta-Hydroxybutyric Acid. J Bacteriol. 82(1961) 33-36.

57. K. Kuchta, L. Chi, H. Fuchs, M. Pötter, A. Steinbüchel. Studies on the Influence of Phasins on Accumulation and Degradation of Poly-3-Hydroxybutyrate and Nanostructure of Poly-3-Hydroxybutyrate Granules in Raistonia eutropha H16. Biomacromol. 8(2) (2007) 657-662.

58. L.A. Huisman. Isolation and Identification of the Reserve Material of B. megaterium. In: Source Book of Experiments for the Teaching of Microbiology. Primrose and Wardlaw (Eds), Academic Press, pp. 233-41, 1982. 59. A.G. Murugesan and D. Radhika. Bioproduction, Statistical Optimization and Characterization of Microbial Plastic (Poly-3-Hydroxybutyrate) Employing Various Hydrolysates of Water Hyacinth (E. crassipes) as Sole Carbon Source. Biores Tech. 121(2012) 83-92.

60. E. Grothe, M. Moo-Young, Y. Chisti. Fermentation Optimization for the Production of Poly (b-Hydroxybutyric Acid) Microbial Thermoplastic. Enzyme Microb. Technol. 25 (1-2) (1999) 132-141.

61. T.G. Benoit, G.R. Wilson, C.L. Baygh. Fermentation During Growth and Sporulation of Bacillus thuringiensis HD-1. Letters Appl Microbiol. 10 (1990) 15-18.

62. D.H. Nam and D.D.Y. Ryu. Relationship Between Butirosin Biosynthesis and Sporulation in Bacillus circulans. Antimicrob Agents Chemother. 27 (1985) 789-801.

63. K. Klüttermann, H. Tauchert, H.P. Kleber. Synthesis of Poly-3-hydroxybutyrate by Agrobacterium radiobacter after Growth on D-Carnitine. Acta Biotechnol. 22(2002) 261-269. 
64. V.S. Reddy, M. Thirumala and S.K. Mahmood. Production of PHB and P (3HB-co-3HV) Biopolymers by Bacillus megaterium Strain OU303A Isolated from Municipal Sewage Sludge. J Microbiol Biotech. 25(3) (2009) 391-397.

65. M.V. Hernandez, N. Gurieff, S. Pratt, P. Magnusson, A. Werker, A. Vargas et al. Rapid Quantification of Intracellular PHA using Infrared Spectroscopy: An Application in Mixed Cultures. J Biotech. 150 (2010) 372379.

66. M. Sandhya, J. Aravind, P. Kanmani. Production of PHAs from Ralstonia eutropha using paddy straw as cheap substrate. Int J Environ Sci Tech. 10(1) (2013) 47-54.

67. S. Chen, Q. Liu, H. Wang, B. Zhu, F. Yu, et al. Polymorphic Crystallization of Fractionated Microbial Medium-Chain-Length PHAs. Polymer. 50 (2009) 4378-4388. 